\title{
Порівняльна характеристика віддалених результатів трансанулярної і нетрансанулярної пластики вихідного тракту правого шлуночка у пацієнтів із подвійним відходженням магістральних судин від правого шлуночка тетрадного типу
}

\author{
Дзюрий І. В., Труба Я. П., Бойко С. М., Балабушка В. О., Руденко М. М., \\ Лазоришинець В.В.
}

ДУ « Національний інститут серцево-судинної хірургії імені М. М. Амосова НАМН» (Київ)

\begin{abstract}
Під терміном подвійне відходження магістральних судин (ПВМС) від правого шлуночка (ПШ) тетрадного типу розуміють аномалію шлуночково-артеріального зв'язку, при якому обидві магістральні артерії повністю або переважно відходять від ПШ, поєднану зі стенозом легеневої артерії (ЛА). Методи радикального лікування полягають у формуванні тунелю правильної конструкції між лівим шлуночком і аортою та в адекватному усуненні обструкції на вихідному тракті правого шлуночка (ВТПШ). Метою роботи було провести порівняльну характеристику віддалених результатів хірургічного лікування подвійного відходження магістральних судин від правого шлуночка тетрадного типу з використанням трансанулярної (ТАП) і нетрансанулярної методики.
\end{abstract}

Матеріали та методи. Із січня 2006 року по грудень 2016 року в ДУ «НІССХ імені М. М. Амосова НАМН» було послідовно прооперовано 33 пацієнти з ПВМС від ПШ тетрадного типу. Залежно від методу усунення стенозу легеневої артерії хворі були поділені на дві групи: першу групу становили 14 (43\%) пацієнтів, яким виконували трансанулярну пластику ВТПШ. До другої групи ввійшли 19 (57\%) пацієнтів, яким виконали різні види нетрансанулярних методик.

Результати. Госпітальна летальність склала 3\% (n=1). Віддалені результати простежені у 30 (90\%) пацієнтів,

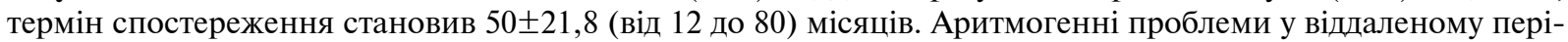
оді відмічались у трьох пацієнтів І групи. У 14 хворих із трансанулярною пластикою градієнт систолічного

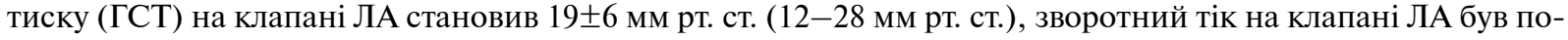
мірним, тоді як у віддаленому періоді спостерігався градієнт 16 $\pm 3,7$ мм рт. ст. (12-23 мм рт. ст.), зворотний тік на клапані ЛА - від помірного до незначного. У 16 пацієнтів, яким проводилася РК зі збереженням кла-

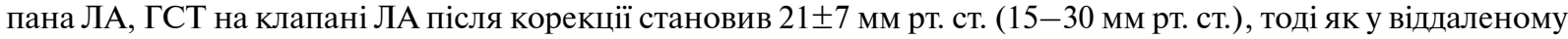
періоді - 19 \pm 6 мм рт. ст. (10-30 мм рт. ст.), а зворотний тік на клапані ЛА був відсутній.

Висновки. Щадна техніка інфундибулярної резекції ВТПШ із збереженням клапана легеневої артерії забезпечує добрі безпосередні та віддалені результати радикальної корекції ПВМС від ПШ тетрадного типу, допомагає зберегти цілісність геометрії та скоротливої функції правого шлуночка, запобігти розвитку багатьох ускладнень у довгостроковій перспективі. Однак віддалена виживаність у групах порівняння статистично не відрізняється.

Ключові слова: подвійне відходження магістральних судин від правого шлуночка тетрадного типу, вроджені вади серия, трансанулярна пластика.

Уперше серце з відходженням обох магістральних судин від правого шлуночка описав хірург Abernathy в 1791 р. Століття по тому, в 1893 р., детальне повідомлення зробив Birmingham. Braun і співавтори [1] в 1952 р. вперше використали термін «шлуночок із двома виходами» (double-outlet ventricle). Witham [2] ввів суттєве уточнення в назву вади - double-outlet right ventricle (DORV).

Частота вроджених вад серця з року в рік залишається стабільною і становить близько 8 на 1000 народжених живими. Подвійне відходження магістральних судин від правого шлуночка належить до найбільш складних ВВС і зустрічається з частотою $1-3 \%$ у загальній кількості серцевих аномалій (J. W. Kirklin et al.) [3]. Під терміном ПВМС від ПШ розуміють аномалію шлуночково-артеріального зв'язку, при якому обидві магістральні артерії повністю або переважно відходять від ПШ. Згідно з класифікацією ЕАCTS виділяють п'ять основних типів ПВМС від ПШ, одним з яких є тетрадний тип, який становить $40-70 \%$ усіх випадків ПВМС від ПШ. ПВМС від ПШ тетрадного типу - суто хірургічна патологія. Ї̈̈ природний перебіг, при якому 
до 3-річного віку гине $40 \%$ дітей, не залишає шансів консервативному лікуванню. Проте навіть при хірургічному втручанні летальність варіює від 6\% до $30 \%$. Більшість дослідників користуються основним правилом визначення ПВМС від ПШ - «правилом 50\%», яке свідчить про те, що магістральна судина належить до того шлуночка, від якого відходить більше ніж 50\% [3]. До цього часу немає єдиної думки щодо вибору тактики реконструкції ВТПШ.

Мета роботи - провести порівняльну характеристику віддалених результатів хірургічного лікування подвійного відходження магістральних судин від правого шлуночка тетрадного типу з використанням трансанулярної та нетрансанулярної методики.

Матеріали та методи. Із січня 2006 року по грудень 2016 року в ДУ «НІССХ імені М. М. Амосова НАМН» послідовно прооперовано 33 пацієнти з ПВМС від ПШ тетрадного типу. Пацієнтів чоловічої статі було 20 (61\%), жіночої - 13 (39\%). Залежно від методу усунення стенозу легеневої артерії хворі були поділені на дві групи: першу групу становили 14 (42\%) пацієнтів, яким виконували трансанулярну пластику ВТПШ. Основними показаннями до виконання трансанулярної пластики ВТПШ була гіпоплазія клапанного кільця та стовбура ЛА. До другої групи ввійшли 19 (57\%) пацієнтів, яким виконали різні види нетрансанулярних методик. Серед пацієнтів, яким зберегли клапан ЛА, у 10 (53\%) випадках виконали пластику в межах ВТПШ, в 1 (5\%) випадку пластику поєднували з вальвулотомією ЛА, у 8 (42\%) випадках виконали черезпередсердночерезлегеневу корекцію. Рішення про виконання клапанозберігаючих операцій приймали на підставі даних про анатомічні особливості ВТПШ, які визначали як на доопераційному етапі, так і під час операції.

Усім пацієнтам перед операцією, а потім інтраопераційно і в післяопераційному періоді виконували загальноклінічні, біохімічні, бактеріологічні дослідження. Усім хворим записували електрокардіографію (ЕКГ), виконували рентгенографію органів груд-

\section{Таблиця 1}

Доопераційні особливості пацієнтів

\begin{tabular}{|c|c|c|c|}
\hline Показники & I група (n=14) & $\begin{array}{l}\text { II група } \\
\text { (n=19) }\end{array}$ & $p$ value \\
\hline $\begin{array}{l}\text { Середній вік } \\
\text { (місяці) }\end{array}$ & $26 \pm 12(8-60)$ & $\begin{array}{c}29 \pm 14 \\
(10-59)\end{array}$ & 0,19 \\
\hline Середня вага (кг) & $\begin{array}{c}11,8 \pm 3,7 \\
(6,4-18,1) \\
\end{array}$ & $\begin{array}{c}11,4 \pm 4 \\
(4,7-20)\end{array}$ & 0,70 \\
\hline $\begin{array}{l}\Delta \text { Р на клапані ЛА } \\
\text { до операції (мм } \\
\text { рт. ст.) }\end{array}$ & $84 \pm 9$ & $82 \pm 6$ & 0,21 \\
\hline \multirow{2}{*}{$\begin{array}{l}\text { Клапан ЛА (см) } \\
\text { (z-score) }\end{array}$} & $0,8 \pm 0,3$ & $1,1 \pm 0,2$ & $<0,05$ \\
\hline & $-2,78$ & $-0,68$ & $<0,05$ \\
\hline
\end{tabular}

\section{Таблиця 2}

Супутні ВВС у пацієнтів з ПВМС від ПШ тетрадного muny

\begin{tabular}{lc} 
Супутні ВВС & Кількість \\
\hline 1. Відкрита артеріальна протока & $3(9 \%)$ \\
\hline 2. Відкрите овальне вікно & $3(9 \%)$ \\
\hline 3.ДМПП & $5(15 \%)$ \\
\hline 4. Множинні ДМШП & $3(9 \%)$ \\
\hline 5. Субаортальний стеноз & $2(6 \%)$ \\
\hline 6. ЧАДЛВ & $3(9 \%)$
\end{tabular}

ДМПП - дефект міжпередсердної перегородки; ДМШП - дефект міжшлуночкової перегородки; ЧАДЛВ - частковий аномальний дренаж легеневих вен

ної клітини в прямій проекції, ЕхоКГ. Катетеризацію порожнин серця з ангіокардіографією виконали у 10 (30\%) випадках, комп'ютерну томографію (КТ) - у 6 (18\%). Метою використання цих методик було підтвердження та уточнення діагнозу, особливо при діагностиці супутніх ВВС. У $57 \%$ пацієнтів із ПВМС від ПШ тетрадного типу патологія поєднувалась із супутніми ВВС (табл. 2).

Основним методом діагностики у визначенні вади та оцінці віддалених результатів було ЕхоКГ-обстеження, що дало змогу оцінити морфологію, кінетику структур серця, стан гемодинаміки. У табл. 3 наведено показники ЕхоКГ-обстеження до операції у пацієнтів, яким виконувалась трансанулярна пластика ВТПШ, порівняно з показниками пацієнтів, яким виконувалися нетрансанулярні методики, що впливали на вибір тактики оперативного лікування.

Для детального вивчення віддалених результатів проводили порівняльну характеристику з передопе-

\section{Таблиця 3}

Порівняльна характеристика розмірів ЛА у пацієнтів з ПВМС від ПШ тетрадного типу в групах порівняння

\begin{tabular}{lccc} 
Показники ЕхоКг & $\begin{array}{c}\text { I група } \\
(\mathbf{n = 1 4 )}\end{array}$ & $\begin{array}{c}\text { II група } \\
(\mathbf{n = 1 9 )}\end{array}$ & p value \\
\hline Стовбур ЛА (см) & $\begin{array}{c}0,9 \pm 0,2 \\
(0,6-1,1)\end{array}$ & $\begin{array}{c}1,2 \pm 0,2 \\
(1,0-1,6)\end{array}$ & $<0,05$ \\
\cline { 2 - 4 } Z-score & $-2,22$ & $-0,36$ & $<0,05$ \\
\hline Права гілка ЛА & $\begin{array}{c}0,8 \pm 0,3 \\
(0,5-1,2)\end{array}$ & $\begin{array}{c}0,8 \pm 0,4 \\
(0,4-1,6)\end{array}$ & 0,4 \\
\cline { 2 - 4 } $\begin{array}{lcc}\text { Z-score } \\
\text { Ліва гілка ЛА (см) }\end{array}$ & $\begin{array}{c}0,7 \pm 0,2 \\
(0,5-1,0)\end{array}$ & $\begin{array}{c}0,8 \pm 0,3 \\
(0,5-1,2)\end{array}$ & 0,4 \\
\cline { 2 - 4 } Z-sсоге & $+0,06$ & $+0,85$ & 0,2 \\
\hline $\begin{array}{l}\text { Індекс Наката } \\
\text { (мм2/м2) }\end{array}$ & 144 & 189 & 0,08
\end{tabular}

ЛА - легенева артерія 
Дзюрий І. В. / Порівняльна характеристика віддалених результатів трансанулярної і нетрансанулярної...

\section{Таблиця 4}

Інтраопераційні показники у групах порівняння

\begin{tabular}{lccc} 
Показник & I група (n=14) & II група ( $\mathbf{n = 1 9 )}$ & p value \\
\hline Час штучного & $102 \pm 19$ & $88 \pm 15$ & $<0,05$ \\
кровообігу (хв.) & $(71-134)$ & $(52-109)$ & \\
\hline Час перетискання & $\begin{array}{c}66 \pm 11 \\
\text { аорти (хв.) }\end{array}$ & $\begin{array}{c}49 \pm 16 \\
(23-65)\end{array}$ & $<0,05$ \\
\hline Відношення тиску & $0,34 \pm 0,05$ & $0,37 \pm 0,04$ & 0,2 \\
ПШ/ЛШ & $28 \pm 6$ & $30 \pm 7$ & 0,1
\end{tabular}

раційними показниками і станом при виписці зі стаціонару. Перша консультація була призначена через 6 місяців після операції, потім щорічно. 3 допомогою ЕхоКГ визначали градієнт тиску на клапані легеневої артерії, ступінь його недостатності, розмір порожнини правого шлуночка, систолічний тиск у правому шлуночку.

Оперативні втручання виконували через серединний доступ із використанням штучного кровообігу (ШК), фармакохолодової кардіоплегії та помірної системної гіпотермії. Дефект міжшлуночкової перегородки у $100 \%$ дітей був розміщений підаортально, середній розмір становив 13,8 $\pm 5,2$ мм $(\varnothing=$ від 6 до 22 мм). Формування тунелю правильної конструкції між лівим шлуночком і аортою досягли у 25 (76\%) дітей за допомогою синтетичної заплати Gore-tex, у 8 (24\%) дітей - за допомогою заплати з аутоперикарда. Трансанулярну пластику вихідного тракту правого шлуночка, показаннями до якої була гіпоплазія клапанного кільця та стовбура ЛА, виконали у 14 (43\%) пацієнтів (табл. 3). В інших 19 (57\%) пацієнтів використали різні види нетрансанулярних методик: у 10 (53\%) випадках виконали пластику в межах ВТПШ, в 1 (5\%) випадку пластику поєднували з вальвулотомією ЛА, у 8 (42\%) випадках виконали черезпередсердно-черезлегеневу корекцію. Також виконали одномоментне усунення супутніх ВВС.

Результати та обговорення. Госпітальна летальність склала $3 \%(\mathrm{n}=1)$. Пацієнту віком 8 місяців було виконано відведення аорти в ЛШ за допомогою синтетичної заплати Gore-tex, трансанулярну пластику ВТПШ за допомогою заплати з аутоперикарда. Післяопераційний період ускладнився двосторонньою пневмонією, сепсисом. Пацієнт помер на 10 -ту добу після оперативного лікування від наростаючої дихальної та поліорганної недостатності. Ускладнення раннього післяопераційного періоду відмічались у 12 (36\%) дітей. I група: у 5 (15\%) - систолічна та діастолічна дисфункція ПШ, у 2 (6\%) - ексудативний плеврит, ще у 2 (6\%) - серцева недостатність та ГПМК. II група: у 3 (9\%) дітей, яким виконувалась вентрикулотомія, серцева та дихальна недостатність. Відношення тиску

\section{Таблиця 5}

Післяопераційна характеристика у групах порівняння

\begin{tabular}{lccc} 
Показники & $\begin{array}{c}\text { I група } \\
\text { (n=14) }\end{array}$ & $\begin{array}{c}\text { II rрупа } \\
\text { (n=19) }\end{array}$ & $\begin{array}{c}\text { p } \\
\text { value }\end{array}$ \\
\hline $\begin{array}{l}\text { Час штучної вентиляції } \\
\text { легень (год.) }\end{array}$ & $12 \pm 6,2$ & $6 \pm 2$ & $<0,05$ \\
\hline Інфузія допамін (мкг/кг/Хв.) & $7 \pm 1,2$ & $4,2 \pm 0,5$ & $<0,05$ \\
\hline $\begin{array}{l}\text { Тривалість перебування } \\
\text { у відділенні інтенсивної }\end{array}$ & $8,1 \pm 3,5$ & $6 \pm 2,3$ & $<0,05$ \\
$\begin{array}{l}\text { терапії (дні) } \\
\text { Ускладнення }\end{array}$ & 9 & 3 & $<0,05$ \\
\hline Летальність & $1(7 \%)$ & - & - \\
\hline $\begin{array}{l}\text { ОР на клапані ЛА після } \\
\text { операції (мм рт. Ст.) }\end{array}$ & $19 \pm 6,2$ & $21 \pm 7,4$ & $<0,05$ \\
\hline $\begin{array}{l}\text { АР на клапані ЛА } \\
\text { віддалений (мм рт. ст.) }\end{array}$ & $16 \pm 3,7$ & $19 \pm 7,2$ & $<0,05$ \\
\hline
\end{tabular}

ПШ/ЛШ у середньому становило в групі I $-(0,34)$, у групі II $(0,37)$ і не перевищувало поріг 0,85 , при якому рекомендується проводити ревізію ВТПШ. Це свідчить про адекватне усунення інфундибулярного стенозу в обох групах. Віддалені результати простежені у 30

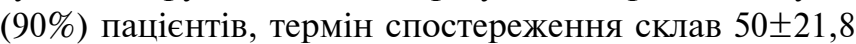
(від 12 до 80) місяців, протягом якого проводився ЕКГ та ЕхоКГ-моніторинг. Аритмогенні проблеми у віддаленому періоді відмічались у 3 (21\%) пацієнтів I групи.

У віддаленому періоді летальних випадків не було. Пацієнти знаходились у I ФК із добрими та II ФК із задовільними згідно з NYHA віддаленими результатами. Треба відзначити той факт, що більшість ускладнень у віддаленому періоді припало на пацієнтів, яким виконувалась ТАП. Оптимальний результат корекції ПВМС від ПШ тетрадного типу гарантується адекватним усуненням обструкції ВТПШ і формуванням тунелю правильної конструкції між лівим шлуночком і аортою.

\section{Таблиця 6}

Ускладнення віддаленого періоду після радикальноі корекції ПВМС від ПШ тетрадного типу у групах порівняння

\begin{tabular}{lccc} 
Ускладнення & $\begin{array}{c}\text { I група } \\
\text { (n=14) }\end{array}$ & $\begin{array}{c}\text { II група } \\
\text { (n=16) }\end{array}$ & p value \\
\hline 1. Решунт ДМШП & 1 & 2 & 0,08 \\
\hline $\begin{array}{l}\text { 2. Недостатність тристулкового } \\
\text { клапана (ТК) }\end{array}$ & 1 & - & - \\
\hline 3. Недостатність на клапані ЛА & 12 & 1 & $<0,05$ \\
\hline 4. Субаортальний стеноз & - & 1 & - \\
\hline 5. Порушення ритму серця & 3 & - & - \\
\hline 6. Аневризма ВТПШ & 8 & 1 & $<0,05$ \\
\hline \multicolumn{1}{|c}{ Всього в групі } & 25 & $\mathbf{5}$ & $<0,05$
\end{tabular}


Викликає занепокоєння той факт, що в більшості пацієнтів, яким виконувалась ТАП, наростає недостатність на клапані ЛА і формуються аневризми на ВТПШ, які в подальшому потрібно буде коригувати хірургічно. Консенсус полягає в тому, що, коли це можливо, легеневий клапанний комплекс слід зберегти. У результаті ми маємо менше безпосередніх і віддалених ускладнень, покрашується довгостроковий результат, що знижує легеневу регургітацію.

\section{Висновки}

1. ЕхоКГ є основним методом діагностики ПВМС від ПШ тетрадного типу, яка допомагає верифікувати діагноз в $100 \%$ випадків, оцінити результати корекції в ранньому післяопераційному та віддалених періодах.

2. Щадна техніка інфундибулярної резекції ВТПШ без ТАП зі збереженням клапана ЛА забезпечує добрі безпосередні та віддалені результати радикальної корекції ПВМС від ПШ тетрадного типу.

3. Трансанулярна пластика ВТПШ забезпечує добрі безпосередні результати, однак у віддаленому періоді в пацієнтів I групи спостерігається наростання недостатності на клапані легеневої артерії (12 пацієнтів, 85\%) та формування аневризми ВТПШ (8 пацієнтів, $57 \%$ ).

4. Відмова від вентрикулотомії може допомогти зберегти цілісність геометрії та скоротливої функції правого шлуночка, запобігти розвитку шлуночкової аритмії в довгостроковій перспективі.

\section{Література}

1. Complete dextroposition of the aorta, pulmonary stenosis, inter-ventricular septal defect, and patent foramen ovale / Braun K., De Vries A., Feingold D. S. et al. // Am Heart J. - 1952. - Vol. 43. - P. 773-80.

2. Witham A. C. Double outlet right ventricle. A partial transposition complex // Am Heart J. - 1957. - Vol. 53. P. 928-39.
3. Kirklin J. W., Barratt-Boyes B. G. Double-Outlet Right ventricle in: Kirklin J. W., Barratt-Boyes B. G., eds Cardiac Surgery 2nd edition. - New York; Churchill Livingstone, 1993. - P. 1469-500.

4. Зиньковский М. Ф. Врожденные пороки сердца. Киев : «Книга-Плюс», 2010. - Гл. 47. - С. 937-970.

5. Assessment of a right-ventricular infundibulum-sparing approach in transatrial-transpulmonary repair tetralogy of Fallot // T. Bove, K. Francois, K. Van De Kerckhove [et al.] // Europ. J. Cardio-Thorac.Surg. - 2012. - Vol. 41. P. $126-133$.

6. Pulmonary valve preservation in Tetralogy of Fallot with a mildly hypoplastic annulus-should we do it? // Indian J Thorac Cardiovasc Surg. - 2011, April-June. - Vol. 27 (2). - P. 76-82.

7. Surgical Strategy for Atrioventricular Septal Defect and Tetralogy of Fallot or Double-Outlet Right Ventricle // Vijayakumar Raju, Harold M. Burkhart, Natalie Rigelman Hedberg [et al.] // Ann Thorac Surg. - 2013. - Vol. 95. P. 2079-85; 2013 by The Society of Thoracic Surgeons.

8. Double Outlet Right Ventricle, Congenital Heart Disease / G. Ottaviani, L. M. Buja, in Cardiovascular Pathology (Fourth Edition), 2016.

9. Double Outlet Right Ventricle Versus Aortic Dextroposition: Morphologically Distinct Defects // ANGELO RESTIVO, MARTA UNOLT, CAROLINA PUTOTTO, AND BRUNO MARINO // Department of Pediatrics, Pediatric Cardiology, University of Rome "La Sapienza". - 2013. Vol. 296. - P. 559-563.

10. Clinical Presentation and Therapy of Tetralogy of Fallot and Double Outlet Right Ventricle / David J. Driscoll // Congenital Heart Diseases: The Broken Heart. - 2016. P. 397-402.

11. Surgical Treatment of Double Outlet Right Ventricle Complicated by Pulmonary Hypertension / Qing-Yu Wu, Dong-Hai Li, Hong-Yin Li [et al.] // Chin Med J (Engl). 2017, Feb 20. - Vol. 130 (4). - P. 409-413.

\title{
Comparative characteristic of long-term results of transnannular and non-transanular repair of the right ventriculic outlet tract in patients with double outlet right ventricle tetralogy of fallo type
}

\author{
Dziuryi I., Truba Y., Rudenko M., Boyko S., Balabushka V., Lazoryshynetz V. \\ National M. M. Amosov Institute of Cardiovascular Surgery National Academy of Medical Sciences of Ukraine (Kyiv)
}

Double outlet right ventricle (DORV), ToF type is discordant ventriculoarterial connection at which both great arteries completely or particularly arise from the right ventricle, combined with stenosis of pulmonary artery. Method of treatment includes tunnel formation of correct construction between the left ventricle and aorta, and adequate right ventricle outflow tract obstruction repair (RVOTO). The main purpose of this work is to make the comparative characteristic of the late-results of surgical treatment of double outlet right ventricle, ToF type using the transannular and non-transannular techniques.

Materials and methods. From January 2006 to December 2016 in "Amosov National Institute of Cardiovascular Surgery NAMS Ukraine", consistently were operated 33 patients with double outlet right ventricle, ToF type. Depending on the method the pulmonary stenosis repair, patients was divided in two groups: first group 14 (43\%) patients, which were performed RVOT transannular repair. Second group 19 (57\%) patients, which were performed different kinds of nontransannular techniques.

Results. Hospital mortality was $3 \%(n=1)$. Late-results was observed in $30(90 \%)$ patients, term of observation was $50 \pm 21,8$ (from 12 to 80 ) months. Arrhythmogenic complications during long-term period were noticed in 3 patients in the first group. 
In 14 patients after transannular repair the systolic pressure gradient (GSP) on the pulmonary valve was $19 \pm 6 \mathrm{mmHg}$ (12$28 \mathrm{mmHg}$ ), pulmonary valve insufficiency is moderate, while in late-period the pulmonary valve insufficiency was observed from moderate to mild $16 \pm 3,7 \mathrm{mmHg}(12-23 \mathrm{mmHg})$. In 16 patients which was performed pulmonary valve-saved repair, systolic pressure gradient on the pulmonary valve after repair was $21 \pm 7 \mathrm{mmHg}(15-30 \mathrm{mmHg})$, while in remote period was $19+6 \mathrm{mmHg}(10-30 \mathrm{mmHg})$, and the pulmonary valve insufficiency is absent.

Conclusions. The less-traumatic technique of RVOTO repair with saving the pulmonary valve, provides good early and long-term results of DORV (ToF type) repair, helps to save geometry RV and right ventricular contraction, and prevent complications in the long-term perspective. However the remote survival statistically is not different in comparison groups.

Key words: double outlet right ventricle tetralogy of Fallot type, congenital heart diseases, transannular repair.

\title{
Сравнительная характеристика отдаленных результатов трансаннулярной и нетрансаннулярной пластики выходного тракта правого желудочка у пациентов с двойным отхождением магистральных сосудов от правого желудочка тетрадного типа
}

\author{
Дзюрий И. В., Труба Я. П., Бойко С. Н., Балабушка В. А., Руденко М. Н., Лазоришинец В. В. \\ ГУ «Национальный институт сердечно-сосудистой хирургии имени Н. М. Амосова НАМН» (Киев)
}

Под термином двойное отхождение магистральных сосудов (ДОМС) от правого желудочка (ПЖ) тетрадного типа понимают аномалию желудочково-артериальной связи, при которой обе магистральные артерии полностью или преимущественно отходят от ПЖ, совмещенную со стенозом легочной артерии (ЛА). Методы радикального лечения заключаются в формировании туннеля правильной конструкции между левым желудочком и аортой и адекватном устранении обструкции выходного тракта правого желудочка (ВТПЖ). Целью работы было провести сравнительную характеристику отдаленных результатов хирургического лечения двойного отхождения магистральных сосудов от правого желудочка тетрадного типа с использованием трансаннулярной (ТАП) и нетрансаннулярной методики.

Материалы и методы. С января 2006 года по декабрь 2016 года в ГУ «НИССХ имени Н. М. Амосова НАМН» было последовательно прооперировано 33 пациента с ДОМС от ПЖ (тетрадный тип). В зависимости от метода устранения стеноза легочной артерии больные были разделены на две группы. Первую группу составили 14 (43\%) пациентов, которым выполняли трансаннулярную пластику ВТПЖ. Второй группе, состоявшей из 19 (57\%) пациентов, выполняли различные виды нетрансаннулярных методик.

Результаты. Госпитальная летальность составила $3 \%(\mathrm{n}=1)$. Отдаленные результаты прослежены у 30 (90\%) па-

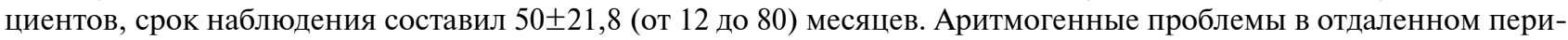
оде отмечались у трех пациентов I группы. У 14 больных с трансаннулярной пластикой градиент систолического давления (ГСД) на клапане ЛА составил 19 \pm 6 мм рт. ст. (12-28 мм рт. ст.), обратный ток на клапане ЛА умеренный. При этом в отдаленном периоде наблюдался градиент 16 $\pm 3,7$ мм рт. ст. (12-23 мм рт. ст.), обратный ток на клапане ЛА - от умеренного до незначительного. У 16 пациентов, которым проводилась РК с сохранением клапана ЛА, ГСТ на клапане ЛА после коррекции составил $21 \pm 7$ мм рт. ст. (15-30 мм рт. ст.), тогда как в отдаленном периоде $19 \pm 6$ мм рт. ст. (10-30 мм рт. ст.), обратный ток на клапане ЛА отсутствовал.

Выводы. Экономная техника инфундибулярной резекции ВТПЖ с сохранением клапана легочной артерии обеспечивает хорошие непосредственные и отдаленные результаты радикальной коррекции ДОМС от ПЖ тетрадного типа, помогает сохранить целостность геометрии и сократительной функции правого желудочка и предотвратить развитие многих осложнений в долгосрочной перспективе. Однако отдаленная выживаемость в группах сравнения статистически не отличается.

Ключевые слова: двойное отхождение магистральных сосудов от правого желудочка тетрадного типа, врожденные пороки сердиа, трансаннулярная пластика. 